\title{
Synthesis of a Chiral Meso-Like Ansa-Zirconocene Complex and its Use for the Catalytic Formation of Low Molecular Weight Polypropylene
}

\author{
Sven Thiele, Gerhard Erker*, Cornelia Fritze, Christian Psiorz, Roland Fröhlich \\ Organisch-Chemisches Institut der Universität Münster, Corrensstraße 40, D-48149 Münster \\ Z. Naturforsch. 50b, 982-989 (1995); received November 11, 1994 \\ Ansa-Metallocene Complex, Homogeneous Ziegler-Type Catalyst, Propene Polymerization \\ Reaction of lithium(neomenthylcyclopentadienid) $\mathbf{3}$ with dimethyldichlorosilane gives \\ dimethylbis[3-(neomenthyl)cyclopentadienyl]silane $\mathbf{4}$ regioselectively as a mixture of \\ double bond shift isomers ( $57 \%$ isolated). Deprotonation with 2 equiv. of butyllithium \\ followed by treatment with zirconiumtetrachloride furnished a mixture of the three \\ \{dimethylsilylenbis $\left[\eta^{5}-3\right.$-(neomenthyl)cyclopentadienyl]\}zirconium dichloride diastereomers \\ from which the pure meso-like isomer $\mathbf{6 c}\left[p-\mathrm{R}\left(1^{\prime} \mathrm{S}, 3^{\prime} \mathrm{R}, 4^{\prime} \mathrm{R}\right), p-\mathrm{S}\left(1^{\prime} \mathrm{S}, 3^{\prime} \mathrm{R}, 4^{\prime} \mathrm{R}\right)\right]$ was isolated \\ by fractional crystallization. Complex $\mathbf{6 c}$ was characterized by an X-ray crystal structure \\ analysis. Its $\mathrm{D} 1-\mathrm{Zr}-\mathrm{D} 2$ angle of $126.8^{\circ}$ is very similar as observed in bis $(\eta$-cyclopenta- \\ dienyl)zirconium dichloride (D1 and D2 denote the centroids of the cyclopentadienyl rings). \\ The homogeneous $\mathbf{6} \mathbf{c} /$ methylalumoxane Ziegler-type catalyst produces polypropylene of low \\ molecular weight $\left(\overline{\mathrm{M}}_{\eta} \approx 670\right.$ at ambient temperature). Related catalyst systems may find \\ interesting applications in organic synthesis.
}

\section{Introduction}

The reaction of a variety of group 4 bent metallocene complexes with an excess of methylalumoxane generates very active homogeneous Zieglertype catalysts for the production of $\alpha$-olefin polymers [1]. It would be highly desirable to develop such systems, which are very reactive and very selective at the same time, into useful catalysts for the formation of monomeric target molecules in organic synthesis. For that reason we are looking for zirconocene derivative/methylalumoxane systems that predominantly favor the formation of rather low molecular weight $\alpha$-olefin oligomers instead of the high molecular weight polymeric materials usually formed at such catalyst systems [2]. During this search we have prepared a variety of novel bent metallocene complexes whose properties have become modified by the attachment of terpenyl substituents at the Cp-ring systems [3]. The synthesis and some properties of an interesting example of this class of compounds is described below.

\footnotetext{
* Reprint requests to Prof. Dr. G. Erker.
}

\section{Results and Discussion}

For the introduction of the terpenyl substituent we have employed the procedure used by Kagan. Cesarotti et al. and treated (+)menthyltosylate (1 S, 3 S, 4 R-2) with sodium cyclopentadienide [4]. The resulting neomenthyl-substituted cyclopentadiene was deprotonated by $n$-butyllithium and the resulting neomenthylcyclopentadienyllithium reagent $\left(1^{\prime} \mathrm{S}, 3^{\prime} \mathrm{R}, 4^{\prime} \mathrm{R}-3\right)$ was treated with 0.5 molar equivalents of dimethyldichlorosilane. We have isolated the corresponding dimethylbis[3-(neomenthyl)cyclopentadienyl $]$ silane $\left[(-) 1^{\prime} \mathrm{S}, 3^{\prime} \mathrm{R}, 4^{\prime} \mathrm{R}-\mathbf{4}\right]$ as a mixture of several double bond shift isomers in $57 \%$ yield. The silyl-bridged bis-Cp-ligand was deprotonated ( $n$-butyllithium/ether) and treated with zirconiumtetrachloride.

Attachment of the transition metal to each of the unsymmetrically 1,3-disubstituted cyclopentadienyl rings has created a pair of planar chirality elements. With the defined chirality centers in the substituent $\left(1^{\prime} \mathrm{S}, 3^{\prime} \mathrm{R}, 4^{\prime} \mathrm{R}\right)$ one may form a total of three diastereoisomeric ansa-metallocene complexes. Two of these contain pairwise identical planar-chirality elements $(p-\mathrm{R}, p-\mathrm{R}$ and $p$-S, $p$-S). Attachment of the pair of homochiral substituents has led to a diastereomeric differentiation [3, 5]. Hence, we may describe these two isomers as the racem-like diastereomers $\mathbf{6 a}$ 
$\left[p-\mathrm{R}\left(1^{\prime} \mathrm{S}, 3^{\prime} \mathrm{R}, 4^{\prime} \mathrm{R}\right), p-\mathrm{R}\left(1^{\prime} \mathrm{S}, 3^{\prime} \mathrm{R}, 4^{\prime} \mathrm{R}\right)\right]$ and $\mathbf{6 b}$ $\left[p-\mathrm{S}\left(1^{\prime} \mathrm{S}, 3^{\prime} \mathrm{R}, 4^{\prime} \mathrm{R}\right), p-\mathrm{S}\left(1^{\prime} \mathrm{S}, 3^{\prime} \mathrm{R}, 4^{\prime} \mathrm{R}\right)\right]$. In addition, the combination of the two elements of planar chirality may be $p$-R, $p$-S. In this case only a single additional diastereoisomer results that we may term meso-like (6c), and which is characterized by the stereochemical descriptor $\left[p-\mathrm{R}\left(1^{\prime} \mathrm{S}, 3^{\prime} \mathrm{R}, 4^{\prime} \mathrm{R}\right), p-\mathrm{S}\left(1^{\prime} \mathrm{S}, 3^{\prime} \mathrm{R}, 4^{\prime} \mathrm{R}\right)\right]$ of the combination of the bent metallocene core and the neomenthyl substituents attached at its Cp-ring systems. The racem-like isomers $\mathbf{6 a}$ and $\mathbf{6 b}$ may exhibit $\mathrm{C}_{2}$-molecular symmetry whereas the mesolike diastereomer exhibits no symmetry element aside from identity. All three complexes must be formed optically active by the synthesis outlined above. In principle all three isomers should be expected to be obtained by this synthetic route. In the ${ }^{1} \mathrm{H}$ NMR spectrum of the crude reaction mixture we have indeed observed signals that may be attributed to the mixture of all three diastereoisomers. Workup and crystallization from $n$-pentane, however, gave only a single complex (isolated in $34 \%$ yield) that was identified as the meso-like diastereomer $\mathbf{6 c}$. The compound is, of course, optically active: $[\alpha]_{\mathrm{D}}{ }^{20}=-48.0^{\circ}(c=1.0$, benzene). The diastereomeric assignment is based on the characteristic NMR spectra and the result of an X-ray crystal structure analysis.

Because of the low overall molecular symmetry $\left(\mathrm{C}_{1}\right.$, see above $)$ the two neomenthylcyclopenta- dienyl moieties of the meso-like complex $\mathbf{6 c}$ are diastereotopic and so are the methylgroups at the bridging silicon atom. Consequently, one observes two $\mathrm{Si}-\mathrm{CH}_{3}{ }^{1} \mathrm{H}$ NMR singulets of $\mathbf{6 c}$ in $\left[\mathrm{D}_{6}\right]$ benzene solution at $\delta=0.09$ and 0.31 in a $1: 1$ ratio. In $\mathrm{CDCl}_{3}$ the signals of the diastereotopic Si-bound methyl groups are isochronic but in this solvent the Cp-methine multiplets are nicely separated: Six resonances are observed as expected $(\delta=5.54$, $5.63,5.92,5.97,6.84,6.97)$, and there are $32{ }^{13} \mathrm{C}$ NMR resonances of $\mathbf{6 c}$ observed. That means that of all the carbon atoms that are differentiated by the symmetry properties of the meso-like diastereomer separate signals are observed in reality. Thus there are two cyclopentadienyl C 1 signals at $\delta=140.3$ and 140.5 . For all other pairs of related carbon centers an even better separation of the ${ }^{13} \mathrm{C}$ NMR resonances is experimentally observed (see Fig. 1.).

Single crystals of $\mathbf{6 c}$ were obtained by slow diffusion of pentane into a solution of the pure mesolike metallocene in dichloromethane. The X-ray crystal structure analysis shows the presence of two independent meso-like ansa-metallocene molecules per unit cell. The two molecules differ only slightly in their bond lengths and angles and in the torsional substituent arrangement. Chemically both are identical molecules.

The substituted cyclopentadienyl ring systems are $\eta^{5}$-coordinated to zirconium. The presence of

Scheme 1

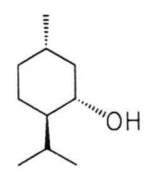

1 (1S, 3S, 4R)

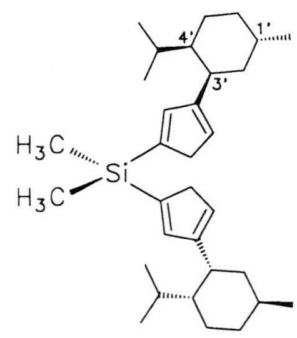

4 ( ' 'S, 3'R, 4'R)

( + double bond

shift isomers)

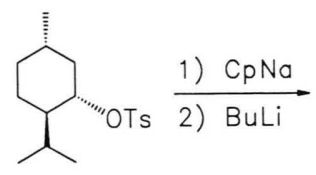

$2(1 \mathrm{~S}, 3 \mathrm{~S}, 4 \mathrm{R})$

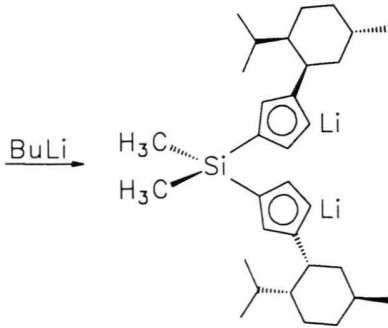

5 ( l'S, 3'R, 4'R)
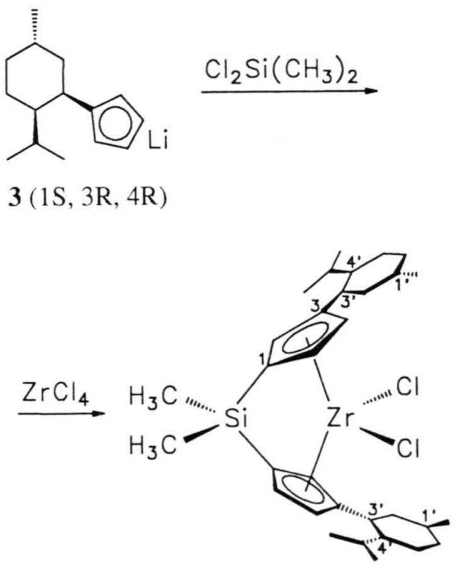

6c [p-R (1'S, 3'R, 4'R), p-S (1'S, 3'R, 4'R)] 


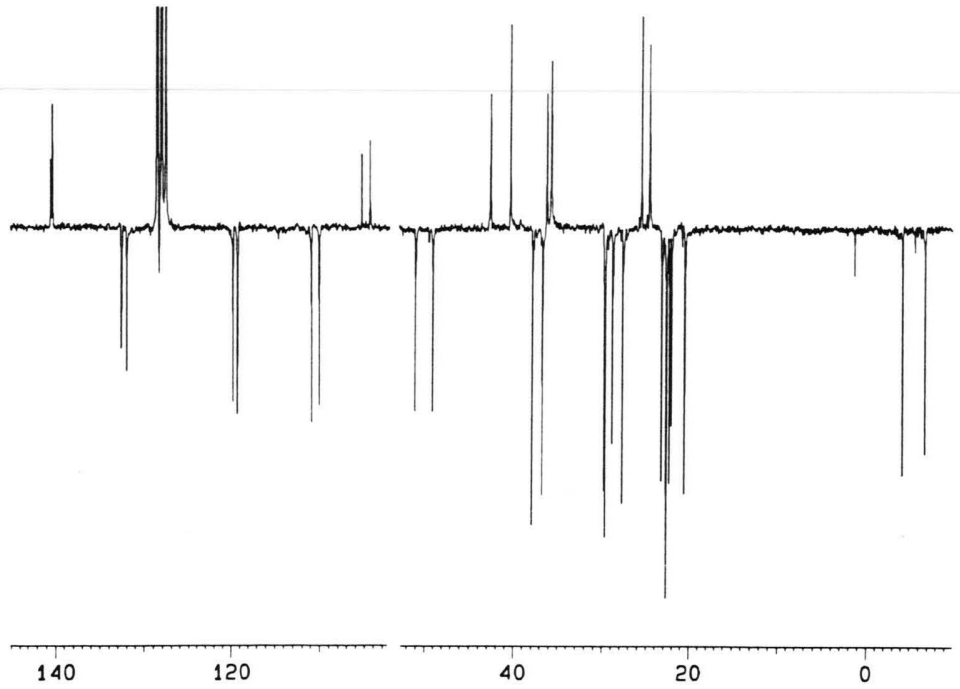

Fig. 1. ${ }^{13} \mathrm{C}$ NMR spectrum (APT [6] in benzene- $\mathrm{d}_{6}$ ) of the meso-like ansa-zirconocene dichloride complex $\mathbf{6 c}$

$\left[p-\mathrm{R}\left(1^{\prime} \mathrm{S}, 3^{\prime} \mathrm{R}, 4^{\prime} \mathrm{R}\right), p-\mathrm{S}\left(1^{\prime} \mathrm{S}, 3^{\prime} \mathrm{R}, 4^{\prime} \mathrm{R}\right)\right.$-configuration]. Quart $\underline{\mathrm{C}}$ and $\mathrm{CH}_{2}$ resonances are pointing up, $\underline{\mathrm{C}} \overline{\mathrm{H}}$ and $\underline{\mathrm{C}} \mathrm{H}_{3}$ signals are pointing down. the short ansa-bridge leads to a pronounced tilting of the Cp-rings. Thus the $\mathrm{Zr}-\mathrm{C}(\mathrm{Cp})$ distances around the $\mathrm{Si}_{1}$-bridge are short (e.g. in molecule 1: $2.476(7) \AA \mathrm{Zr}-\mathrm{C} 11,2.455(7) \mathrm{Zr}-\mathrm{C} 12,2.515(7)$ $\mathrm{Zr}-\mathrm{C} 10)$ whereas the remaining two distal $\mathrm{Zr}-\mathrm{C}(\mathrm{Cp})$ bonds are markedly longer (e.g. in molecule 1: 2.604(6) $\mathrm{Zr}-\mathrm{C} 13,2.653(7) \mathrm{Zr}-\mathrm{C} 14$; for additional related values see Table I). The $\mathrm{Si}-\mathrm{C}\left(\mathrm{CH}_{3}\right)$ bonds are 1.854(10) and 1.849(10) $\AA$ (in mol 1). The adjacent $\mathrm{Si}-\mathrm{C}(\mathrm{Cp})$ bonds between $\mathrm{Si}$ and the (formally) $\mathrm{sp}^{2}$-hybridized carbon centers are in the same range $(1.851(7) \AA \mathrm{Si}-\mathrm{C} 11$, 1.858(7) $\mathrm{Si}-\mathrm{C} 15$, mol 1). The ansa-metallocene angle at $\mathrm{Si} 1$ is $94.2(3)^{\circ}(\mathrm{C} 11-\mathrm{Si} 1-\mathrm{C} 15$ in mol 1). The angle between the best $\mathrm{Cp}$-planes in $\mathbf{6 c}$ is $116.7^{\circ}(\mathrm{mol} 1) / 117.7^{\circ}(\mathrm{mol} 2)$. This indicates that the $\mathrm{C}(\mathrm{Cp})-\mathrm{Si}$ vectors are oriented out of the $\mathrm{Cp}$ - planes into the direction toward the zirconium center. The corresponding torsional angles are $\theta=$ $-162.0(5)^{\circ}(\mathrm{C} 13-\mathrm{C} 12-\mathrm{C} 11-\mathrm{Si} 1)$, $160.7(5)^{\circ}(\mathrm{C} 14-\mathrm{C} 10-\mathrm{C} 11-\mathrm{Si} 1)$, $160.2(6)^{\circ}(\mathrm{C} 17-\mathrm{C} 16-\mathrm{C} 15-\mathrm{Si} 1)$, $-161.6(5)^{\circ}(\mathrm{C} 18-\mathrm{C} 19-\mathrm{C} 15-\mathrm{Si} 1)(\mathrm{mol} 1) /$ $-159.7(6)^{\circ}(\mathrm{C} 23-\mathrm{C} 22-\mathrm{C} 21-\mathrm{Si} 2)$, $160.2(5)^{\circ}(\mathrm{C} 24-\mathrm{C} 20-\mathrm{C} 21-\mathrm{Si} 2)$, $159.4(5)^{\circ}(\mathrm{C} 29-\mathrm{C} 25-\mathrm{C} 26-\mathrm{Si} 2)$, and $-161.3(5)^{\circ}(\mathrm{C} 28-\mathrm{C} 27-\mathrm{C} 26-\mathrm{Si} 2)(\mathrm{mol} 2)$.

The $\mathrm{D} 1-\mathrm{Zr}-\mathrm{D} 2$ angle is $126.8^{\circ}(\mathrm{mol} 1) / 126.9^{\circ}$ (mol 2) (D1 and D 2 denote the centroids of the Cp-ring systems). This characteristic bent metallocene "bite angle" in $\mathbf{6 c}$ is very close to the value observed for the unbridged parent zirconium complex $\mathrm{Cp}_{2} \mathrm{ZrCl}_{2}$ (D1-Zr-D 2: 126.0, Cl1-Zr-Cl2: $97.2^{\circ}$ ) [7]. The $\mathrm{Cl} 1-\mathrm{Zr}-\mathrm{Cl} 2$ angle in $6 \mathbf{c}$ is much

Table I. Selected bond lengths $(\AA)$ and angles $\left(^{\circ}\right)$ of $6 \mathbf{c}$.

\begin{tabular}{|c|c|c|c|c|c|c|c|c|}
\hline \multicolumn{4}{|l|}{ Mol. 1} & \multicolumn{4}{|l|}{ Mol. 2} & \multirow{2}{*}{$\begin{array}{l}\text { Average } \\
2.471\end{array}$} \\
\hline $\mathrm{Zr} 1-\mathrm{C} 11$ & $2.476(7)$ & $\mathrm{Zr} 1-\mathrm{C} 15$ & $2.455(7)$ & $\mathrm{Zr} 2-\mathrm{C} 21$ & $2.484(8)$ & $\mathrm{Zr} 2-\mathrm{C} 26$ & $2.467(6)$ & \\
\hline $\mathrm{Zr} 1-\mathrm{C} 10$ & $2.515(7)$ & Zr $1-C 19$ & $2.494(7)$ & $\mathrm{Zr} 2-\mathrm{C} 20$ & $2.522(7)$ & $\mathrm{Zr} 2-\mathrm{C} 27$ & $2.505(7)$ & 2.509 \\
\hline $\mathrm{Zr} 1-\mathrm{C} 14$ & $2.653(7)$ & Zr $1-C 18$ & $2.619(6)$ & $\mathrm{Zr} 2-\mathrm{C} 24$ & $2.634(6)$ & $\mathrm{Zr} 2-\mathrm{C} 28$ & $2.636(7)$ & 2.636 \\
\hline $\mathrm{Zr} 1-\mathrm{C} 13$ & $2.604(6)$ & Zr $1-\mathrm{C} 17$ & $2.581(8)$ & $\mathrm{Zr} 2-\mathrm{C} 23$ & $2.569(7)$ & $\mathrm{Zr} 2-\mathrm{C} 29$ & $2.573(6)$ & 2.582 \\
\hline $\mathrm{Zr} 1-\mathrm{C} 12$ & $2.455(8)$ & $\mathrm{Zr} 1-\mathrm{C} 16$ & $2.475(7)$ & $\mathrm{Zr} 2-\mathrm{C} 22$ & $2.446(7)$ & $\mathrm{Zr} 2-\mathrm{C} 25$ & $2.461(6)$ & 2.459 \\
\hline $\mathrm{Zr} 1-\mathrm{Cl} 11$ & $2.431(2)$ & $\mathrm{Zr} 1-\mathrm{Cl} 12$ & $2.423(2)$ & $\mathrm{Zr} 2-\mathrm{Cl} 21$ & $2.432(2)$ & $\mathrm{Zr} 2-\mathrm{Cl} 22$ & $2.418(2)$ & 2.426 \\
\hline Si $1-C 1$ & $1.849(10)$ & Si $1-C 2$ & $1.854(10)$ & $\mathrm{Si} 2-\mathrm{C} 3$ & $1.848(8)$ & $\mathrm{Si} 2-\mathrm{C} 4$ & $1.852(10)$ & 1.851 \\
\hline \multicolumn{2}{|c|}{$\mathrm{Cl} 11-\mathrm{Zr} 1-\mathrm{Cl} 12$} & \multicolumn{2}{|l|}{$102.77(10)$} & \multicolumn{2}{|c|}{$\mathrm{Cl} 21-\mathrm{Zr} 2-\mathrm{Cl} 22$} & \multicolumn{2}{|l|}{$102.62(10)$} & 102.70 \\
\hline \multicolumn{2}{|c|}{$\mathrm{Cp} \mathrm{p}^{\mathrm{a}} / \mathrm{Cp}^{\mathrm{b}}$} & \multicolumn{2}{|l|}{116.7} & \multicolumn{2}{|c|}{$\mathrm{Cp}^{\mathrm{c}} / \mathrm{Cp}^{\mathrm{d}}$} & \multicolumn{2}{|l|}{117.7} & 117.2 \\
\hline \multicolumn{2}{|c|}{$\mathrm{D} 1-\mathrm{Zr} 1-\mathrm{D} 2$} & \multicolumn{2}{|l|}{126.8} & \multicolumn{2}{|c|}{ D $3-\mathrm{Zr} 2-\mathrm{D} 4$} & \multicolumn{2}{|l|}{126.9} & 126.9 \\
\hline \multicolumn{2}{|c|}{$\mathrm{C} 1-\mathrm{Si} 1-\mathrm{C} 2$} & \multicolumn{2}{|l|}{$115.4(5)$} & \multicolumn{2}{|c|}{$\mathrm{C} 3-\mathrm{Si} 2-\mathrm{C} 4$} & \multicolumn{2}{|l|}{$114.3(4)$} & 114.9 \\
\hline \multicolumn{2}{|c|}{$\mathrm{C} 11-\mathrm{Si} 1-\mathrm{C} 15$} & \multicolumn{2}{|l|}{$94.2(3)$} & \multicolumn{2}{|c|}{$\mathrm{C} 21-\mathrm{Si} 2-\mathrm{C} 26$} & $94.2(3)$ & & 94.2 \\
\hline
\end{tabular}



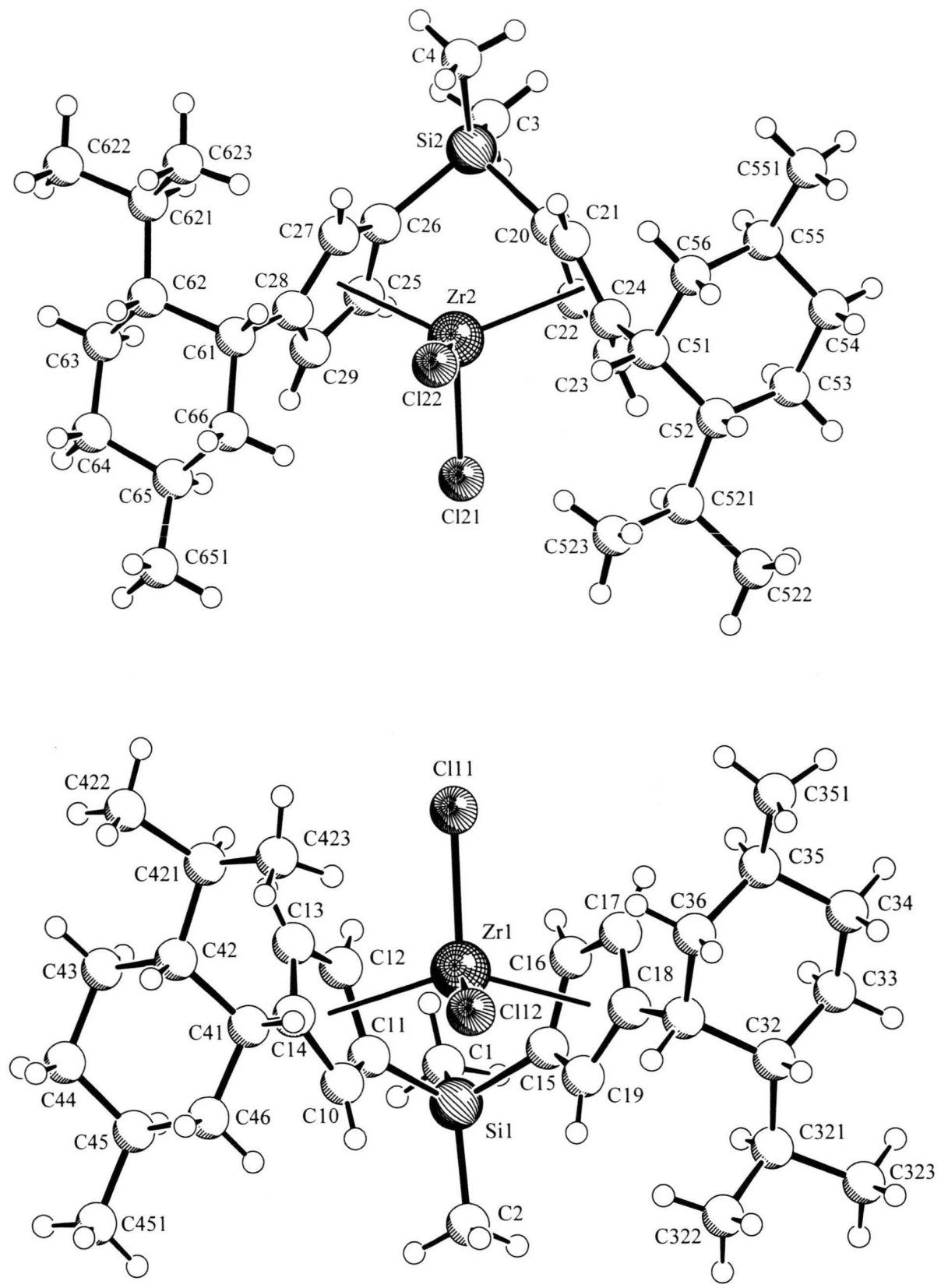

Fig. 2. Views of the crystallographically independent molecules of $\mathbf{6 c}$ (with unsystematical atom numbering scheme).

larger at $102.8^{\circ}(\mathrm{mol} \mathrm{1}) / 102.6^{\circ}(\mathrm{mol} 2)$. This is not a feature introduced by the very bulky terpenyl substituents but rather an effect brought about by the ansa structure. Related open unbridged metallocene complexes are bis $\left(\eta^{5}-1\right.$-neomenthylcyclopentadienyl)zirconium dichloride and ( $p$-S, $p$-S)- bis $\left(\eta^{5}\right.$-1-neomenthylindenyl)zirconium dichloride that exhibit $\mathrm{Cl}-\mathrm{Zr}-\mathrm{Cl}$ angles of $95.2^{\circ}$ and $91.6^{\circ}$ and $\mathrm{D} 1-\mathrm{Zr}-\mathrm{D} 2$ angles of $128.5^{\circ}$ and $129.5^{\circ}$, respectively. The ansa-zirconocene complex ethylene(bistetrahydroindenyl)zirconium dichloride exhibits a D $1-\mathrm{Zr}-\mathrm{D} 2$ angle of $125.2^{\circ}$ [7]. 
Table II. Atomic coordinates $\left(\times 10^{4}\right)$ and equivalent isotropic displacement parameters $\left(\mathrm{A}^{2} \times 10^{3}\right)$ for $\mathbf{6 c}$. $\mathrm{U}_{\mathrm{eq}}$ is defined as one third of the trace of the orthogonalized $\mathrm{U}_{\mathrm{ij}}$ tensor.

\begin{tabular}{|c|c|c|c|c|}
\hline Atom & $x$ & $y$ & $z$ & $\mathrm{U}_{\mathrm{eq}}$ \\
\hline $\mathrm{Zr}(1)$ & $13452(1)$ & $9370(1)$ & $4157(1)$ & $30(1)$ \\
\hline $\mathrm{Cl}(11)$ & $11176(2)$ & $8448(2)$ & $3405(2)$ & $54(1)$ \\
\hline $\mathrm{Cl}(12)$ & $12850(3)$ & $10749(2)$ & $5479(2)$ & $61(1)$ \\
\hline $\mathrm{Si}(1)$ & $16644(2)$ & $8921(2)$ & $3582(1)$ & 39(1) \\
\hline$C(1)$ & $16980(11)$ & 7797(8) & $2575(7)$ & $58(2)$ \\
\hline C(2) & $18225(9)$ & $9817(9)$ & $4261(7)$ & $59(2)$ \\
\hline$C(10)$ & 15111(8) & $8629(7)$ & $5142(5)$ & $35(1)$ \\
\hline$C(11)$ & $15405(8)$ & $8174(6)$ & $4236(5)$ & $37(2)$ \\
\hline$C(12)$ & $14200(9)$ & $7335(7)$ & $3847(5)$ & $41(2)$ \\
\hline$C(13)$ & 13251(8) & $7214(6)$ & $4501(5)$ & $36(2)$ \\
\hline$C(14)$ & $13810(8)$ & $8022(6)$ & $5316(5)$ & $34(1)$ \\
\hline$C(15)$ & $15437(8)$ & $9976(6)$ & $3344(5)$ & $36(2)$ \\
\hline$C(16)$ & $14237(8)$ & $9669(6)$ & $2718(5)$ & $36(1)$ \\
\hline$C(17)$ & $13345(9)$ & $10573(7)$ & $2938(5)$ & $36(2)$ \\
\hline$C(18)$ & $13964(8)$ & 11463(6) & $3706(5)$ & $32(2)$ \\
\hline$C(19)$ & $15215(8)$ & $11078(6)$ & $3956(5)$ & $36(1)$ \\
\hline$C(31)$ & $13481(7)$ & $12653(5)$ & $4147(5)$ & $32(1)$ \\
\hline$C(32)$ & $14257(7)$ & $13747(6)$ & $3824(5)$ & $38(1)$ \\
\hline$C(321)$ & $15863(8)$ & 13899(6) & $3932(6)$ & $46(2)$ \\
\hline$C(322)$ & $16378(10)$ & $14103(8)$ & $4903(7)$ & $68(3)$ \\
\hline $\mathrm{C}(323)$ & $16554(10)$ & 14934(8) & $3558(10)$ & $80(4)$ \\
\hline$C(33)$ & $13669(9)$ & $13717(7)$ & $2876(6)$ & $47(2)$ \\
\hline$C(34)$ & 12098(9) & $13808(7)$ & $2859(6)$ & $52(2)$ \\
\hline$C(35)$ & $11244(9)$ & $12786(8)$ & $3196(7)$ & $51(2)$ \\
\hline$C(351)$ & 9734(10) & $13002(11)$ & $3263(9)$ & $76(3)$ \\
\hline$C(36)$ & $11900(7)$ & $12671(6)$ & $4077(6)$ & $43(2)$ \\
\hline$C(41)$ & $13257(8)$ & $8176(6)$ & $6226(5)$ & $34(1)$ \\
\hline$C(42)$ & $12124(9)$ & $7150(7)$ & $6355(5)$ & $48(2)$ \\
\hline$C(421)$ & 10689(11) & $7032(13)$ & $5850(7)$ & $82(4)$ \\
\hline$C(422)$ & $9633(14)$ & $6105(14)$ & $6192(15)$ & $136(8)$ \\
\hline$C(423)$ & 10134(11) & $8217(14)$ & $5984(10)$ & $88(4)$ \\
\hline$C(43)$ & $12746(14)$ & $5947(8)$ & $6230(7)$ & $66(3)$ \\
\hline$C(44)$ & $14033(15)$ & $6066(9)$ & $6882(7)$ & $76(3)$ \\
\hline$C(45)$ & $15136(12)$ & $7124(11)$ & $6830(7)$ & $65(3)$ \\
\hline $\mathrm{C}(451)$ & $16356(16)$ & $7268(17)$ & $7520(9)$ & $105(5)$ \\
\hline$C(46)$ & $14465(8)$ & $8299(7)$ & $6936(5)$ & $46(2)$ \\
\hline $\operatorname{Zr}(2)$ & $10002(1)$ & 9998(1) & 9976(1) & $32(1)$ \\
\hline $\mathrm{Cl}(21)$ & $12330(2)$ & $10596(3)$ & $10738(2)$ & $59(1)$ \\
\hline $\mathrm{Cl}(22)$ & $10425(3)$ & $8617(2)$ & $8609(1)$ & $61(1)$ \\
\hline $\mathrm{Si}(2)$ & $6846(2)$ & $10700(2)$ & $10477(2)$ & $40(1)$ \\
\hline$C(3)$ & $6353(10)$ & $11709(7)$ & $11494(6)$ & $50(2)$ \\
\hline $\mathrm{C}(4)$ & $5363(10)$ & $9997(10)$ & $9643(7)$ & $59(2)$ \\
\hline$C(20)$ & $8015(8)$ & $8385(6)$ & $10104(5)$ & $35(1)$ \\
\hline $\mathrm{C}(21)$ & $7856(8)$ & $9506(6)$ & $10723(5)$ & $37(2)$ \\
\hline $\mathrm{C}(22)$ & $9019(8)$ & $9713(6)$ & $11350(5)$ & $37(2)$ \\
\hline$C(23)$ & $9803(9)$ & $8733(7)$ & $11154(5)$ & $36(2)$ \\
\hline$C(24)$ & 9192(8) & $7897(6)$ & $10384(5)$ & $33(1)$ \\
\hline$C(25)$ & $9595(9)$ & $12147(6)$ & $10379(5)$ & $39(2)$ \\
\hline$C(26)$ & $8327(8)$ & $11456(6)$ & $9941(5)$ & $37(2)$ \\
\hline $\mathrm{C}(27)$ & $8608(8)$ & $11034(6)$ & $9050(5)$ & $38(2)$ \\
\hline $\mathrm{C}(28)$ & $9985(9)$ & $11503(7)$ & $8911(5)$ & $38(2)$ \\
\hline $\mathrm{C}(29)$ & $10601(8)$ & $12180(6)$ & $9750(5)$ & $36(2)$ \\
\hline$C(51)$ & $9550(8)$ & $6640(6)$ & $9936(5)$ & $41(2)$ \\
\hline$C(52)$ & $10504(8)$ & $6059(6)$ & $10498(5)$ & $46(2)$ \\
\hline$C(521)$ & $12032(10)$ & $6706(8)$ & $10689(10)$ & $77(4)$ \\
\hline$C(522)$ & $12898(12)$ & $6026(16)$ & $11205(10)$ & $100(5)$ \\
\hline$C(523)$ & $12727(13)$ & $6789(16)$ & $9847(13)$ & $121(7)$ \\
\hline$C(53)$ & 9799(11) & $5853(8)$ & $11310(6)$ & $53(2)$ \\
\hline$C(54)$ & $8378(9)$ & $5031(7)$ & $11071(6)$ & $54(2)$ \\
\hline $\mathrm{C}(55)$ & $7412(10)$ & $5510(7)$ & $10447(7)$ & $52(2)$ \\
\hline $\mathrm{C}(551)$ & $6074(11)$ & $4577(10)$ & $10195(10)$ & $81(3)$ \\
\hline$C(56)$ & $8179(9)$ & $5716(7)$ & $9655(5)$ & $52(2)$ \\
\hline $\mathrm{C}(61)$ & $10560(8)$ & $11334(7)$ & $8009(5)$ & $39(2)$ \\
\hline $\mathrm{C}(62)$ & $10166(9)$ & $12324(7)$ & $7522(5)$ & $45(2)$ \\
\hline $\mathrm{C}(621)$ & $8578(11)$ & $12373(11)$ & $7429(7)$ & $62(2)$ \\
\hline$C(622)$ & $8244(15)$ & $13421(15)$ & $7029(10)$ & $99(4)$ \\
\hline$C(623)$ & $7812(11)$ & $11147(12)$ & $6872(7)$ & $75(3)$ \\
\hline $\mathrm{C}(63)$ & $11066(12)$ & $13544(8)$ & $7936(7)$ & $61(2)$ \\
\hline$C(64)$ & 12601(11) & $13455(9)$ & $7846(7)$ & $67(3)$ \\
\hline$C(65)$ & 13131(10) & $12491(10)$ & $8279(6)$ & $59(2)$ \\
\hline $\mathrm{C}(651)$ & $14612(11)$ & $12291(13)$ & $8042(8)$ & $79(3)$ \\
\hline $\mathrm{C}(66)$ & $12151(8)$ & $11273(7)$ & $8002(5)$ & $49(2)$ \\
\hline
\end{tabular}

Table III. Details of the X-ray crystal structure analysis of $6 \mathbf{c}$.

$\begin{array}{lc}a(\AA) & 9.665(1) \\ b(\AA) & 11.336(1) \\ c(\AA) & 15.532(1) \\ \alpha\left({ }^{\circ}\right) & 103.25(1) \\ \beta\left({ }^{\circ}\right) & 92.60(1) \\ \gamma\left({ }^{\circ}\right) & 97.45(1) \\ \text { Volume }\left(\AA^{3}\right) & 1637.5(2) \\ \text { Space group } & \mathrm{P} 1(\text { No. } 1) \\ Z & 2 \\ R(\mathrm{I} \geq 2 \sigma(\mathrm{I})) & 0.052 \\ w R^{2}(\mathrm{I} \geq 2 \sigma(\mathrm{I})) & 0.164 \\ \text { Reflections } & 7093 \\ \text { Parameters } & 666\end{array}$

Programs used: SHELXS-86, SHELXL-93, SCHAKAL-92. Further details of the crystal structure investigation are available from Fachinformationszentrum Karlsruhe, Gesellschaft für wissenschaftlich-technische Information mbH, D-76344 Eggenstein-Leopoldshafen, on quoting the depository number CSD 401418, the names of the authors, and the journal citation.

Complex 6 was used as a component for generating an active homogeneous Ziegler-type catalyst for propene polymerization. For this purpose the ansa-metallocene dichloride was dissolved in toluene and activated by treatment with a large excess of oligomeric methylalumoxane (MAO). In this study $\mathrm{Al} / \mathrm{Zr}$ ratios of $>1000$ were employed. Propene was added to the catalyst solution and the polymerization allowed to proceed for a given period of time. The polypropylene formed was isolated after quenching the mixture with $\mathrm{HCl}$ in methanol. In all cases clear oily products were obtained that were characterized by NMR spectroscopy with regard to their stereochemical constitution and molecular weight. The latter was carried out by ${ }^{1} \mathrm{H}$ NMR end group analysis of the polymers PP2-PP6 (see Table IV). This was possible as only rather low molecular weight polymers were obtained, of which the $\mathrm{H}_{2} \mathrm{C}=\mathrm{C}\left(\mathrm{CH}_{3}\right)$ - end groups were clearly visible. The molecular weight of the obtained products was dependent on the polymerization temperature, ranging from $\bar{M}$ $\sim 4400$ at $0^{\circ} \mathrm{C}$ to $\overline{\mathrm{M}} \sim 670$ at ambient temperature when the polymerization was carried out in a glass autoclave at a propene pressure of 2 bar.

The stereochemistry of the polymers was characterized by ${ }^{13} \mathrm{C}$ NMR methyl pentade analyses [8]. The polypropylenes PP 1-PP 3 obtained at low polymerization temperatures are all completely atactic. They exhibit a $\mathrm{mmmm}$ methyl pentade res- 


\begin{tabular}{lcccccc}
\hline Polymer & $\mathrm{T}\left({ }^{\circ} \mathrm{C}\right)$ & $\mathrm{p}($ bar $)$ & $\mathrm{Al} / \mathrm{Zr}$ & $\mathrm{act}^{\mathrm{a}}$ & $\% \mathrm{mmmm}^{\mathrm{b}}$ & $\overline{\mathrm{M}}_{\eta}^{\mathrm{c}}$ \\
\hline PP1 & -15 & 2 & 1320 & 140 & 11.6 & $>20000^{\mathrm{d}}$ \\
PP2 & 0 & 2 & 1237 & 340 & 10.7 & 4400 \\
PP3 & 13 & 2 & 1100 & 470 & 10.1 & 2800 \\
PP4 & 22 & 2 & 1979 & 210 & 12.7 & 670 \\
PP5 & 80 & 12 & 1979 & 50 & 16.4 & 500 \\
PP6 & 80 & 20 & 1320 & 1200 & 16.1 & 380 \\
\hline
\end{tabular}

Table IV. Propene polymerization at the $6 \mathbf{c} / \mathrm{MAO}$ catalyst system.

a Activities in $\mathrm{g}$ polymer/g $[\mathrm{Zr}] \cdot \mathrm{h} \cdot \mathrm{bar} ;$ b by ${ }^{13} \mathrm{C}$ NMR methyl pentade analysis; ${ }^{c}$ by ${ }^{1} \mathrm{H}$ NMR end group analysis; ${ }^{d}$ estimated from the ${ }^{1} \mathrm{H}$ NMR spectrum.

onance at $\delta=21.9$ (in 1,2,4-trichlorobenzene solution at $80^{\circ} \mathrm{C}$ ) of $c a \cdot 10-11 \%$ intensity. It appears that the $\mathrm{mmmm}$ resonance is slightly intensified with increasing polymerization temperature. This is visualized in the ${ }^{13} \mathrm{C}$ NMR spectra of the polypropylenes PP 4-PP 6 where the mmmm pentade signal has become the highest peak in the methyl resonance region. Polypropylene PP 4 (polymerization carried out at room temperature) has a $12.7 \% \mathrm{mmmm}$ intensity. The $\mathrm{mmmm}$ intensity value further increases to values of $c a .16 \%$ when the catalytic propene coupling process is carried out at $+80^{\circ} \mathrm{C}$ (PP 5, PP 6, see Table IV) [9]. In this case only propene oligomers are obtained with spectroscopically easily identified $\mathrm{H}_{2} \mathrm{C}=\mathrm{C}\left(\mathrm{CH}_{3}\right)-$ end groups $\left({ }^{13} \mathrm{C} \mathrm{CH}_{3}\right.$ resonance at $\left.\delta=22.6\right)$.

\section{Conclusions}

The ansa-metallocene system $\mathbf{6}$ is easily prepared by a straightforward synthetic route. Of the three possible diastereomers we have isolated complex 6c, for which we have secured a mesolike structure containing a $p-\mathrm{R}, p-\mathrm{S}$ combination of chirality elements. The presence of two homochiral neomenthylsubstituents (with $1^{\prime} \mathrm{S}, 3^{\prime} \mathrm{R}, 4^{\prime} \mathrm{R}$ configuration) makes this complex chiral. It is optically active since the overall synthesis was carried out using enantiomerically pure $(+)$ menthol as the chiral starting material.

With the exception of the $\mathrm{Cl} 1-\mathrm{Zr}-\mathrm{Cl} 2$ angle the structural properties of the ansa-metallocene backbone are very similar as found in the parent compound bis(cyclopentadienyl)zirconium dichloride. The homogeneous metallocene/methylalumoxane Ziegler-type catalyst system derived from 6c thus produces polypropylenes with a similarly low molecular weight as does the $\mathrm{Cp}_{2} \mathrm{ZrCl}_{2} / \mathrm{MAO}$ catalyst system. In $\mathbf{6} \mathbf{c} / \mathrm{MAO}$ neither the silylbridge nor the attached bulky terpenyl substituents lead to a significant enhancement of the molecular weight of the product. This is not an unfavorable situation as it may guide a way to generate novel ansa-metallocene derived catalyst systems for useful applications in organic synthesis, e.g. for the catalytic intramolecular coupling of nonconjugated diolefinic starting materials to produce cyclic alkene monomers [10].

For such a development it would be very desirable to obtain a high selectivity at high reaction rates with such a catalyst systems. Unfortunately, the polymeric material formed at the $6 \mathbf{c} / \mathrm{MAO}$ catalyst at ambient temperature or below is completely atactic. Here, the chiral terpenyl substituents do not at all overcome the dominating influence of the achiral meso-type $p$-R, $p$-S metallocene backbone. Interestingly, the stereoselectivity of product formation is slightly increased with increasing temperature $[9,11]$, although this is not a strong effect at this catalyst system. At present it is unclear whether this effect is due to an increased chain end or enantiomorphic site control becoming of increased importance at elevated temperatures. Whatever the reason is, this observation makes us optimistic that the related ansa-metallocene dichlorides containing the chiral $p-\mathrm{R}^{*}, p-\mathrm{R}^{*}$ combination of planar chirality elements might be suited precursors for selective ansa-metallocene derived homogeneous Ziegler-type catalyst systems to be used in organic synthesis. We are currently trying to develop selective organometallic syntheses of such optically active ansa-metallocene complexes.

\section{Experimental Section}

Reactions were carried out in an inert atmosphere (argon) using Schlenk-type glassware or in a glove-box. All solvents were dried and distilled under argon prior to use. Lithium[1-(neomenthyl)cyclopentadienid] (3) was prepared analogously as described in the literature [4]. Propene polymerization reactions and the polymer analysis were carried out similarly as described by us previously $[3,5]$. For a description of additional general ex- 
perimental details including a list of spectrometers used for product characterization see ref. 3 .

\section{(-)Dimethylbis[3-(neomenthyl)cyclopentadienyl]- silane (4)}

The lithium[1-(neomenthyl)cyclopentadienid] (1' $, 3^{\prime} \mathrm{R}, 4^{\prime} \mathrm{R}-\mathbf{3}, 8.38 \mathrm{~g}, 40 \mathrm{mmol}$ ) was dissolved in $40 \mathrm{ml}$ of tetrahydrofuran. To this solution was added a solution of $2.58 \mathrm{~g}(20 \mathrm{mmol})$ of dimethyldichlorosilane in $16 \mathrm{ml}$ of $\mathrm{THF}$ at room temperature during $30 \mathrm{~min}$. The mixture was stirred for $3 \mathrm{~h}$ and then poured onto ice. Phases were separated and the aqueous phase extracted with ether $(3 \times 20 \mathrm{ml})$. The combined organic phases were dried over magnesium sulfate. Solvent was removed in vacuo and the oily residue chromatographed with pentane at silica gel to give $2.63 \mathrm{~g}$ $(57 \%)$ of $\mathbf{4}$ as a mixture of two double bond shift isomers $(\mathrm{A}: \mathrm{B} \approx 1: 2),[\alpha]_{\mathrm{D}}^{20}=-17.0^{\circ}(\mathrm{c}=0.97$, benzene). ${ }^{1} \mathrm{H}$ NMR ([D 6 benzene): $\delta=6.65,6.45$, 6.39 (m, each 2 H, Cp), 2.90-3.45 (m, 6 H, Cp- $\underline{\mathrm{H}}_{2}$ and terpenyl-3' $\left.{ }^{\prime} \underline{\mathrm{H}}\right), 0.60-2.00(\mathrm{~m}, 36 \mathrm{H}$, terpenylhydrogens), 0.06 and $-0.22\left(2 \times \mathrm{bs}, 6 \mathrm{H}, \mathrm{Si}\left(\mathrm{CH}_{3}\right)_{2}\right.$ of $\mathrm{A}$ and $\mathrm{B}$ ).

\section{Dilithium \{dimethylsilylenbis[3-(neomenthyl)- cyclopentadienyl]\} ( $\left.1^{\prime} S, 3^{\prime} R, 4^{\prime} R-5\right)$}

Dimethylbis[3-(neomenthyl)cyclopentadienyl]silane $(4,3.52 \mathrm{~g}, 7.6 \mathrm{mmol})$ was dissolved in $50 \mathrm{ml}$ of tetrahydrofuran. $n$-Butyllithium $(11.9 \mathrm{ml}$ of a $1.6 \mathrm{M}$ ethereal solution, $18.9 \mathrm{mmol}$ ) was added dropwise at room temperature. The mixture was stirred for $2 \mathrm{~d}$, solvent was then removed in vacuo and the remaining product washed with pentane $(2 \times 30 \mathrm{ml})$ to give $2.9 \mathrm{~g}(80 \%)$ of 5 . ${ }^{1} \mathrm{H}$ NMR ([D $]$ tetrahydrofuran): $\delta=5.97,5.92,5.83(\mathrm{~m}$, each $2 \mathrm{H}, \mathrm{Cp}), 3.21\left(\mathrm{~m}, 2 \mathrm{H}, 3^{\prime}-\mathrm{H}\right), 0.60-2.20(\mathrm{~m}, 36 \mathrm{H}$, neomenthyl-hydrogens), -0.12 (bs, $\left.6 \mathrm{H}, \mathrm{Si}\left(\mathrm{CH}_{3}\right)_{2}\right)$. ${ }^{13} \mathrm{C}$ NMR ([D 8 tetrahydrofuran): $\delta=124.5,113.9$, 111.0, 108.4 (Cp), 50.8, 46.8, 39.8, 37.6, 31.1, 28.5, 26.8, 24.1, 22.8, 21.7 (neomenthyl-C), 3.1 $\left(\mathrm{Si}\left(\underline{\mathrm{CH}}_{3}\right)_{2}\right)$, one $\mathrm{Cp}$-carbon not located.
\{Dimethylsilylenbis $/ \eta^{5}-3$-(neomenthyl)cyclopentadienyl]\} dichlorozirconium $\left[p-R\left(1^{\prime} S, 3^{\prime} R, 4^{\prime} R\right)\right.$, $\left.p-S\left(1^{\prime} S, 3^{\prime} R, 4^{\prime} R\right) \mathbf{6 c}\right]$

Zirconiumtetrachloride $(1.2 \mathrm{~g}, 5.2 \mathrm{mmol})$ was added in several portions to a stirred suspension of $5(2.5 \mathrm{~g}, 5.3 \mathrm{mmol})$ in $200 \mathrm{ml}$ of toluene at $-78^{\circ} \mathrm{C}$. The mixture was stirred for $30 \mathrm{~min}$ at $-78^{\circ} \mathrm{C}$, then allowed to warm slowly to room temperature during $10 \mathrm{~h}$ and then stirred for additional $2 \mathrm{~d}$. A precipitate (lithium chloride) was removed by filtration. Solvent was removed in vacuo. The residue was characterized by ${ }^{1} \mathrm{H}$ NMR spectroscopy. It contained three products in an approximate $5: 2: 3$ ratio, the major product later proved to be the meso-like complex 6c. Pentane $(40 \mathrm{ml})$ was added to the residue and stirred for $1 \mathrm{~d}$. The pentane phase was separated, concentrated to about half its original volume and kept at $-30{ }^{\circ} \mathrm{C}$ for 2 weeks. The crystallized compound 6c was collected by filtration $(1.1 \mathrm{~g}, 34 \%)$, m.p. $196{ }^{\circ} \mathrm{C}(\mathrm{DSC}),[\alpha]_{\mathrm{D}}{ }^{20}=-48.0^{\circ}(\mathrm{c}=1.0$, benzene $)$. Slow diffusion of pentane into a solution of $\mathbf{6 c}$ in dichloromethane gave single crystals for the X-ray crystal structure analysis of $\mathbf{6 c}$ (for details see Table III). ${ }^{1} \mathrm{H}$ NMR ([D $]$ benzene): $\delta=7.14,7.08$, 5.78, 5.71, 5.69, $5.66(\mathrm{~m}$, each $1 \mathrm{H}, \mathrm{Cp}), 3.93,3.73$ (m, each $\left.1 \mathrm{H}, 3^{\prime}-\mathrm{H}\right), 2.85-0.55(\mathrm{~m}, 36 \mathrm{H}$, neomenthyl-hydrogens), 0.31, 0.09 (s, each $\left.3 \mathrm{H}, \mathrm{Si}\left(\mathrm{C}_{3}\right)_{2}\right)$. ${ }^{13} \mathrm{C}$ NMR ([D $]$ benzene): $\delta=140.5,140.3,132.5$, 131.9, 119.7, 119.2, 110.9, 110.0, 105.2, 104.3 (Cp). 51.1, 49.1 (C3'), 42.7, 40.5, 36.3, 35.8, 25.6, 24.7 $\left(\mathrm{CH}_{2}\right), 37.9,36.7,29.8,29.6,28.8,27.7$ (remaining neomenthyl $\mathrm{CH}), 23.2,22.8,22.7,22.3,22.1,20.5$ (neomenthyl $\left.\mathrm{CH}_{3}\right),-4.2,-6.8\left(\mathrm{Si}\left(\underline{\mathrm{CH}}_{3}\right)_{2}\right)$.

Analysis for $\mathrm{C}_{32} \mathrm{H}_{50} \mathrm{Cl}_{2} \mathrm{SiZr}(625.0)$

Calcd C 61.50 H 8.06\%,

Found C 61.56 H 8.17\%.

\section{Acknowledgements}

Financial support from the Fonds der Chemischen Industrie, the Bundesminister für Forschung und Technologie, the EC (COST-program), and the Alfried Krupp von Bohlen und Halbach-Stiftung is gratefully acknowledged.
[1] H. Sinn, W. Kaminsky, Adv. Organomet. Chem. 18, 99 (1980); W. Kaminsky, K. Külper, H. H. Brintzinger, F. R. W. P. Wild, Angew. Chem. 97, 507 (1985); Angew. Chem., Int. Ed. Engl. 24, 507 (1985); W. Spaleck, M. Antberg, J. Rohrmann, A. Winter, B. Bachmann, P. Kiprof, J. Behm, W. A. Herrmann, Angew. Chem. 104, 1373 (1992); Angew. Chem.,
Int. Ed. Engl. 31, 1347 (1992), and references cited therein.

[2] G. Erker, C. Psiorz, C. Krüger, M. Nolte, Chem. Ber. 127, 1551 (1994); G. Erker, C. Psiorz, R. Fröhlich, M. Grehl, Tetrahedron, in press; G. Erker. C. Psiorz, R. Fröhlich, Z. Naturforsch., submitted for publication. 
[3] G. Erker, B. Temme, J. Am. Chem. Soc. 114, 4004 (1992); G. Erker, Pure Appl. Chem. 64, 393 (1992); G. Erker, M. Aulbach, M. Knickmeier, D. Wingbermühle, C. Krüger, M. Nolte, S. Werner, J. Am. Chem. Soc. 115, 4590 (1993).

[4] E. Cesarotti, H. B. Kagan, R. Goddard, C. Krüger, J. Organomet. Chem. 162, 297 (1978); E. Cesarotti, R. Ugo, H. B. Kagan, Angew. Chem. 91, 842 (1979); Angew. Chem., Int. Ed. Engl. 18, 779 (1979); E. Cesarotti, R. Ugo, R. Vitiello, J. Mol. Catal. 12, 63 (1981).

[5] G. Erker, M. Aulbach, D. Wingbermühle, C. Krüger, S. Werner, Chem. Ber. 126, 755 (1993); G. Erker, M. Aulbach, C. Krüger, S. Werner, J. Organomet. Chem. 450, 1 (1993); C. Krüger, F. Lutz, M. Nolte, G. Erker, M. Aulbach, J. Organomet. Chem. 452, 79 (1993).

[6] S. L. Patt, J. N. Shoolery, J. Magn. Reson. 46, 535 (1982).

[7] U. Höweler, R. Mohr, M. Knickmeier, G. Erker, Organometallics 13, 2380 (1994) and references cited therein.

[8] F. A. Bovey, G. V. D. Tiers, J. Polym. Sci. 44, 173 (1960); R. A. Sheldon, T. Fueno, R. Tsuntsuga, J. Kurukawa, J. Polym. Sci., Part B. 3, 23 (1965); A.
Zambelli, P. Locatelli, G. Bajo, F. A. Bovey, Macromolecules 8, 1565 (1975); J. Inoue, Y. Itabashi, R. Chujo, Y. Doi, Polymer 25, 1640 (1984); M. Farina, Top. Stereochem. 17, 1 (1987); G. Erker, R. Nolte, Y.-H. Tsay, C. Krüger, Angew. Chem. 101, 642 (1989); Angew. Chem., Int. Ed. Engl. 28, 628 (1989); G. Erker, R. Nolte, R. Aul, S. Wilker, C. Krüger, R. Noe, J. Am. Chem. Soc. 113, 7594 (1991).

[9] G. Erker, C. Fritze, Angew. Chem. 104, 204 (1992); Angew. Chem., Int. Ed. Engl. 31, 199 (1992); L. Resconi, L. Abis, G. Franciscono, Macromolecules 25, 6814 (1992).

[10] J. R. Young, J. R. Stille, Organometallics 9, 3022 (1990); W. E. Piers, J. E. Bercaw, J. Am. Chem. Soc. 112, 9406 (1990); W. E. Piers, P. J. Shapiro, E. E. Bunel, J. E. Bercaw, Synlett 74 (1990); G. A. Molander, J. O. Hoberg, J. Am. Chem. Soc. 114, 3123 (1992); see also: G. W. Coates, R. M. Waymouth, J. Am. Chem. Soc. 115, 91 (1993); X. Yang, L. Jia, T. J. Marks, J. Am. Chem. Soc. 115, 3392 (1993).

[11] H. Buschmann, H.-D. Scharf, N. Hoffmann, P. Esser, Angew. Chem. 103, 480 (1991); Angew. Chem., Int. Ed. Engl. 30, 477 (1991); B. Giese, Acc. Chem. Res. 17, 438 (1984), and references cited in these articles. 